\title{
Correction to: Holding an entity mind-set deters consumption of recycled content products: the role of perceived product quality
}

\section{Sohyun Bae ${ }^{1}$}

Published online: 31 July 2021

(c) Springer-Verlag GmbH Germany, part of Springer Nature 2021

\section{Correction to:International Review on Public and NonprofitMarketing https://doi.org/10.1007/s12208-021-00285-4}

Table 3 should be the below:

The original article can be found online at https://doi.org/10.1007/s12208-021-00285-4.

Sohyun Bae

shbae0102@gs.ncku.edu.tw

1 Institute of International Business, National Cheng Kung University, No. 1, University Road, Tainan 701, Taiwan 


\section{Appendix B}

Table 3 Stimuli in Studies 1, 2 and 3

Study 1 Imagine that you are planning to buy headphones. When you search for them online, you find Sony headphones that suit your need. Upon further reading, you realize that they are made with recycled materials. The price of the headphones is $\$ 49.99$, which is affordable for you.

Study 2 Imagine that you go out shopping for a table lamp. Which option would you prefer?

Product A: Target table lamp with a cloth shade made from recycled cotton.

Product B: Target table lamp with a cloth shade made from organic cotton.

Imagine that you need to buy new running shoes. Two options are available. Which option do you prefer?

Product A: Nike running shoes made with recycled materials.

Product B: Nike running shoes made with new materials.

Study 3 Made from recycled cotton

Again Jean is a company that buys old, worn-out clothing from second-hand sellers and recycles them to manufacture new denim. It has recently launched its new denim jacket made from recycle cotton.

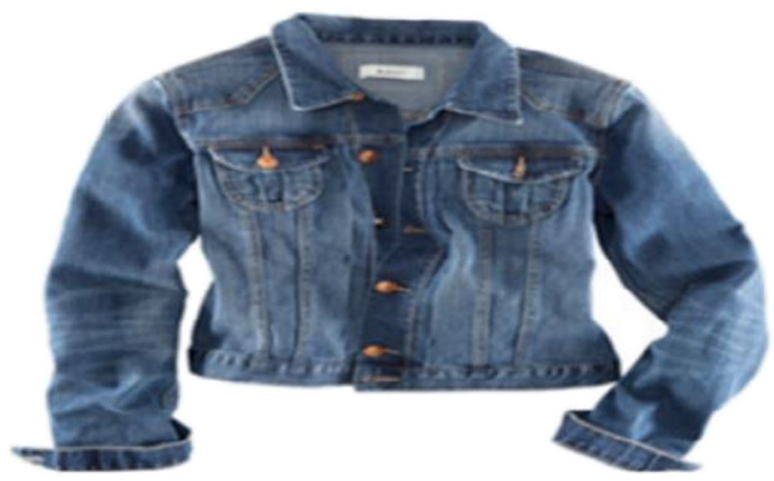

The original article has been corrected.

Publisher's note Springer Nature remains neutral with regard to jurisdictional claims in published maps and institutional affiliations. 